\title{
Deconstructing Denominationalism in Igboland: A Liturgy of Bitterness
}

\author{
Patrick Enoch Nmah \\ http://dx.doi./org/10.4314/ujah.v21i1.1
}

\begin{abstract}
This research work aimed at examining the effects of denominationalism in Igboland. The study revealed bitterness, antagonism, rivalry, moral barrenness, and spiritual bankruptcy that are dangers associated with denominationalism. Findings showed also the strengths and weaknesses of this narrow-minded party spirit in the area under review. The work recommended effective ecumenical-dialogue, exchange of programme, and inter-denominational communication as panacea to the challenges of party spirit. Methods of approach are historical and phenomenological methods coupled with the review of related extant materials. It concluded that shying away from engaging in interdenominational relations through media for the purposes of Christian unity and evangelization amounts to playing the ostrich which has dire consequences. This paper assessed the challenges of worshipping God with bitterness among Igbo Christians. The problem is not planting Christianity in Igboland, but the method of evangelization which depends basically on denominationalism characterized by bitterness, envy, hatred, jealousy, wickedness and covetousness by which many Igbo Christians practice their faith. This in turn has adverse effect on the moral, social, intellectual and spiritual growth of the society. The bitterness is often within and without the denominations. The antagonistic attitude is seen among denominations such as Roman Catholic, Anglican, Methodist, Presbyterian, Seventh Day Adventist, Assemblies of God Church among others (Nmah, 2008).
\end{abstract}

Keywords: Denominationalism, Deconstruction, Bitterness, Liturgy, Antagonism. 


\section{Introduction}

Luke 9:49-56 presents two lessons on tolerance. There were many exorcists in Palestine, all claiming to be able to cast out demons, and no doubt John regarded this man as a competitor and wished to eliminate him. But Jesus would not permit him. The direct way from Galilee to Jerusalem led through Samaria, but most Jews avoided it. There was a centuries old quarrel between the Jews and Samaritans (John 4:9). The Samaritans in fact did everything they could to hinder and even to injure any band of Pilgrims who attempted to pass through their territory.

For Jesus to take that way to Jerusalem was unusual, and to attempt to find hospitality in a Samaritan village was still much unusual. When he did this he was extending a hand of friendship to a people who were enemies. In this case not only was hospitality refused, but the offer of friendship was spurned. No wonder that James and John believed that they were doing a praiseworthy thing when they offered to call in divine did to blot out the village. But Jesus would not permit them.

There is no passage in the Bible where Jesus so directly teaches the duty of tolerance as in this. In many ways tolerance is a lost virtue, and often, where it does exist, it exists from the wrong cause. Of all the greatest religious leaders, none was such a pattern of tolerance as John Wesley:

I have no more right, he said, to object to a man for holding a different opinion from mine than I have to differ with a man because he wears a wig and I wear my own hair; but if he takes his wig off and shakes the powder in my face, I shall consider it my duty to get quit of him as soon as possible... The thing which I resolved to use every possible method of preventing was a narrowness of spirit, a party 
zeal, a being straitened in our own bowels-that miserable bigotry which makes many so unready to believe that there is any work of God but among themselves... We think and let think (Barclays, 1982, p.130).

When his nephew, Samuel, the son of his brother Charles, entered the Roman Catholic Church, he wrote to him, "Whether in this Church or that I care not. You may be saved in either or damned in either; but I feared you are not born again." The Methodist invitation to the sacrament is simply, "Let all who love the Lord come here." The conviction that certain denominational beliefs and methods alone are correct has been the cause of more tragedy and distress in the church than almost any other thing.

\section{Conceptual Framework}

The word liturgy is derived from the Greek word "leitourgia" ("public duty"). It has come to refer to the act of public worship, especially as it pertains to Christian church services. But its emphasis, though subtle, has quite literally changed the landscape and influenced daily life. According to Willlis (2007), the kind of building we associate with the word "church" is a direct result of the liturgy it was designed for. The formal liturgical tradition of the Catholic Mass, for instance, called forth the Gothic Cathedral. The simple tradition of the Quaker meeting produced a less formal design. The New England Meeting House places the preacher and his pulpit front and center, while many modern sanctuaries look more like the "theatre in the round" with full-scale media rooms controlling sound and lighting equipment. Beginning with reforms of Vatican II Councils in 1963, Roman Catholic liturgy forced a change in furniture placement. In an effort to include more lay 
participation, the priest now stood behind the altar, facing the people. Previously, he had stood with his back to the people, facing the altar.

When organs began to be used to accompany liturgy, churches were built around the demands of the instrument itself. Organ pipes began to be a recognizable part of the liturgical furniture. Now, with many Protestant churches employing modern instruments, it is not uncommon for churches to be built around orchestra pits and stages, with giant screens behind the worship leader so as to project the words of songs or highlight the text of the lecturer's sermon. Liturgy dictates architecture. Architecture displays theology. Theology demands liturgy. The three cannot be separated (Douglas, 1974).

To Livingstone (1980), the word liturgy is used in two senses: (1) of all the prescribed services of the church; as contrasted with private devotion, and (2) especially in the Eastern Church, as a title for the Eucharist. In derived senses it is also used both of the written texts which order services and of the study of these. According to Ekpunobi (2001), denomination is derived from the English word denominate which means, "To give a name to, to designate, to style." It means also a class, and a religious sect. A denomination is an independent and distinct religious group, different from other congregations. Denominations opt out of the mainstream because of their desire to emphasize one particular doctrine or the other. Some grow out of discontent with the teaching and organization of the orthodox Church. They usually set up their own system of organization and administration. They take names that will distinguish them from others. It is a sect or group of religious congregations having its own organization and a distinctive faith. Denominationalism is a class spirit or policy, devotion to the interests of a sect or denomination. It could 
be described as a narrow-minded adherence to a particular sector party or denomination.

Denominationalism was one of the factors used by the colonial masters to maintain their power for effective control of the colonies. The European powers saw Africa (Igboland inclusive) as open to them for acquisition and hence they "scrambled" for territories and areas of influence therein. In order to create some order out of the chaos caused by such scrambling, Prince Bismarch convened for a conference of the European powers in Berlin in 1885 to determine and discuss the "spheres of influence" of each European power in Africa. These colonialists navigated into Africa alongside their national churches (Uka, 1980). What really revolutionized the European attitude to Africa was not the prospect of sending Christian missions to Africa, but the discovering of its potential wealth which is designed primarily to serve the best selfinterest of the colonial powers, especially their economic interest, as Karl Marx would argue (Uka, 1980).

Deconstruction is a philosophical theory of criticism (usually of literature or film) that seeks to expose deep seated contradictions in a work by delving below its surface meaning.

\section{Research Objectives}

The purpose of the study includes:

- To x-ray the effects of denominationalism among Christians in Igbo land.

- To investigate the causal factors in respect of denominationalism.

- To examine also the factors that enhance the thriving of denominationalism in the area of study.

- To highlight why these churches have not been able to fulfil the prayer of Jesus, the great high priest to be one in diversity. 
- To propose the necessary steps required for engaging in ecumenical dialogue in order to recover the church's morality, spirituality, intellectuality and effective evangelism.

\section{Significance of the Study}

The significance of the research work basically stems from the fact that it addresses the issue that threatened the collective mission ad intra and mission ad extra. The former denotes mission within the church in terms of preaching and catechesis and engaging Pious Societies in various missionary enterprises, while the latter has to do with engaging in ecumenism with Christianity of other faith. The work offers a valid and insightful resource related extant material for further studies on deconstructing denominationalism among Igbo Christians for future religious, sociological, and anthropological scholars especially church historiographers who consult such documents in order to gain useful information on the topic.

\section{Literature Review and Hypotheses}

\section{Causes of Bitterness among Christian Denomination in Igboland}

In Igboland and especially in Anambra, Imo and Enugu states, the denominations vie to win the influence of those that are rich at the detriment of the poor and marginalized. These men and women are more often than not brought to bear their wealth on the churches through building gigantic Cathedrals and pro-cathedrals, halls, among others not-with-standing the sources of their wealth. At times many bishops and priests become unsolicited chaplains and counsellors to such deified personalities coupled with becoming self-made political advisers to the "president, governors, parliamentarians, permanent secretaries and the like", aimed not to 
feed them spiritually but to satisfy their egocentric material needs or expectations of personal material gains.

Their sarcastic comments could also be seen in primary and secondary schools alongside tertiary institutions in the states aforementioned. This in turn encourages more corruption among some of the parishioners who will like to get rich by all means in order to be relevant to the current system. This abets also overt or covert corruption in the society.

The hate speech could be at intra-congregational and intercongregational levels apart from intra-denomination or interdenomination squabble or hate speech rhetoric. The body of Christ has been turned into something else other than edified body by some fake Christians. Denominational bickering, as people find it existing among the so-called Christians today, may, in the second place be due to political cause (Oldham, 1924). The tension between Catholics, and Anglicans and Protestants in Anambra, Imo and Enugu states is largely created by the difficulties inherent in alien ecclesiastical rule. On one side the exercise of power and the sense of belonging to a privileged caste or social stratification is apt to breed an attitude of superiority or inferiority complex, arrogance and disdain which provokes resentment or sentiment.

Some of the hate speeches made especially during Eucharistic service in inviting Catholic faithful or Anglican faithful to Holy Communion by the respective priests include: "The Holy Communion is meant for those their respective bishops confirmed". But they forgot that prior to it; those priests have invited worshippers to give their offerings irrespective of their denominations. That is a huge irony of the whole issues. A mockery of Christian virtues. The problem continues unabated.

\section{The Desire for Political Influence or Spiritual Independence}


The desire for political influence or spiritual independence is, however, quite distinct from feeling connected with the physical and mental differences of the parishioners, though these may colour and intensify the denominational feeling when it has been aroused. Further illustration of the part played by political causes in determining denominational likes and dislikes is furnished by the changes which have passed over the feelings of a particular denomination towards other churches in recent years. Their emotional attitude towards the different denominations has varied from time to time. This is according to the political action or aims of each were judged to be friendly or the reverse.

\section{Denominational Hatred Due to Spiritual Differences}

In the third place, denominational hatred may arise from spiritual differences in denominational temperament and character, doctrine and dogma. Some denominations like or dislike certain type of denomination(s), and whether the cause be an innate difference in disposition or the moulding influence of social tradition, they find it actual experience a much larger number of the type they like in their denomination, and of the type they dislike in a different denomination.

\section{Differences in Civilization}

Difficulties may arise from differences in civilization. Civilization is something quite distinct from denomination, but since the two often coincide, they are apt to be confused. Differences in civilization are not necessarily repellent. They may attract and stimulate. The periods of greatest progress have often followed in the contact of two different civilizations and their mutually stimulating effects. Foreign customs frequently fascinate and are eagerly imitated. But while Igbo people are often ready like any 
other African ethnic group to borrow foreign ideas and foreign fashions, they do this only for their own free choice. They are at other times resolute to resist any change in their inherited customs and familiar ways such as traditional burial rite in Awka, Ogidi or elsewhere in Anambra state of Nigeria versus the Catholic Church and Anglican churches respectively.

The difference between the peoples in denominations, traditions, customs, social conversion and consequently in habits of thought and feeling, are so great that the surprising thing is not that they should give rise to difficulties in inter or intra-denominational intercourse and understanding, but rather that these difficulties should in so many instances be overcome (Oldman,1924).

\section{Challenges of Superiority or Inferiority Complex}

Fifthly, a very fruitful cause of denominational bitterness is found in the feelings of superiority complex in certain areas of influence by any of the denominations on the one hand, which are apt to be engendered by the existing political and economic predominance of the churches from the West. At times it may also depend on inferiority complex. Some of the denominations feel that they are global in outlook, while other churches are localized in a particular area.

\section{Questions of Inter Marriages}

Again, there is the question of inter marriages or mixed marriages. In the view of much repugnance to inter marriage is the fundamental cause of denominational prejudice. It is often difficult for an Anglican and other churches to marry a Catholic and vice versa. When such occurs the parties (couple) alongside their parents are either ex-communicated, suspended or they relocate to a neutral church. According to Chiegboka (2009), "Where Catholic parents give out their daughters to non-Catholic, they incur the 
penalty of suspension from the sacraments unless they show noncorporation by not taking dowry and accepting wine" (p.16). In practice, this denial of sacrament extends to denial of funeral Mass. Again, parents and those taking the place of parents, who hand over their children to be baptized or brought up in a non-Catholic religion, are to be punished with a censure or other just penalty. This shows also the degree of intolerance among the Igbo Christians.

In the Acts of the Apostles, these tensions lie beneath the surface, but Paul's letter to the Galatians brings them into the open. The antagonism was between circumcision party and uncircumcision party. Paul was angry with those who were still trying to make Gentile Christians believe that they needed to be circumcised (Gal. 5:2-6, Rom. 2:25, 29; 1 Cor. 7:19). He was angry that he had still been obliged to argue with Peter who took meals with Gentile Christians in Antioch, but changed his mind and kept himself aloof when rebuked by envoys from James in Jerusalem. In the early Christian history, there were also a variety of teachers each on his own theology. Such include Eusebius, Origen, Marcion, Montanus, Augustine, Tertullian, Justin, Arius, Athanasius, Martin Luther, John Calvin, and Donatus among others.

Anyadele (1966) observes that the only man who discerned from the beginning the palpable danger of Christian missions to the social and political heritage of Southern Nigeria, and who spared no efforts to destroy the new-fangled faith was king Jaja of Opobo, the greatest political figure in the Bights of Benin and Biafra. The destruction of the Arochukwu oracle by the British expedition under Lieutenant Colonel Montanaro from December, 1901 until March, 1912 opened up the whole of Igboland to British rule. Both 
the Roman Catholic and Church Missionary Society (C.M.S) joined in the scramble for land and area of influence in Igboland.

In such inter-denominational theology of bigotry, all tactics were used to woo converts' sentiment and emotion. Schools, hospitals, skill acquisition centres, war of words and material gifts became veritable tools for making Igbo converts and evangelism. The Igbo converts with their inter and intra-village competitiveness exploited the religious bigotry to the fullest. For many people especially the outcastes, slaves and twin mothers and their babies, captives, etcetera, the church provided shelter, propaganda and brain washing centres.

The Roman Catholics generously distributed medicines thereby upsetting the C.M.S by the use of alluring temporal advantages to win converts. The Anglicans applied same in Enugu State. Notwithstanding that C.M.S was already well established thirty years before the Catholics came from Gabon, the latter are today as much established in Igboland as the Anglicans (Kalu, 1978). Not minding that Crowther gave Father Lutz land, it was the Anglican opposition that constituted most formidable obstacle to Catholic expansion. As the Holy Ghost Fathers were French, their incursion into British sphere of influence implicated the missionary antagonism in the imperialist scramble.

Among the other denominations, the most aggressive mission body was the Primitive Methodists. From Ikot Ekpene, the Methodists moved to the interior of Igboland within two decades covered Ariam, Ndoro and Bende led by Christie and Rev F.W. Dodds. Their expansion into Igboland was much influenced by the construction of the rail road at Ovim, Umuahia, Uzuakoli, Enugu, Port Harcourt and Aba (Methodist Church Nigeria, 2010).

The roots of denominational bickering and a times violence go back to the history of missionary era. Historical analysis of 
denominational conflict, its causes and preconditions, has been highly contentious in character. Nmah (2008) argues that there is more continuity between past and present, extending backward at least to the early eighteenth century upward. The emergence of independent churches in Igboland did not settle the differences between Anglicans and Catholics or the other denominations, but rather aggravated the rivalry.

As much as religion is common historical foundation for the bigotry, it has also been the source of animosity and many have sought to down play the aspect of religion. The antagonism is usually seen also in church owned institutions such as schools, hospitals, hostels, cottage industries and in governance. Because this bickering includes at times "church versus state dimension," many fans of these institutions use them as forums to vent deeply hate feelings and perceptions. Through these perceptions, the thrill of victory and the sting of defeat are magnified. Nepotism in politics, economic, social and religious worship characterized the religious bigotry.

\section{Recommendations}

First, the Christians business is to seek first the kingdom of God and his righteousness (Matt. 6:33). A Christian is dedicated to the service of God who is over flowingly alive and who has a definite moral purpose for the world. Consequently, in the light of that commanding, universal purpose of righteousness and love, natural or denominational differences which exist among men become insignificant.

Second, since God loves men and seeks their common good, Christians are dedicated to the service of their fellow men. The love of Christ becomes a constraining motive. Life becomes a 
mission, a call to uncalculating service. This love, since it is divine, surmounts all barriers.

These principles of conduct by which the attitude of Christians must be governed- the supremacy of moral values, reverence for human personality and the dedication of life to the service of mankind- are thankfully recognized, accepted today by many who do not profess and call themselves Christians. Large numbers outside the Christian Church share the conviction that in the more determined application of these conceptions to the life of the world lays only hope of saving human society from complete collapse. Denominations are not because they are only "off-shoots" of the one true church.

Again, the Christian Association of Nigeria, the Christian Council of Nigeria, and the Pentecostal Fellowship of Nigeria can create Facebook or Whatsapp page or twitter handle wherein different denominations can access or share information. The need for inter-denominational or institutional website where basic information about denominations or the institutions can be accessed is also expedient. There should be downward flow of communication which involves passing information from superiors to subordinates which allows also superiors to implement their decision in a way that it will influence employees who are lower in hierarchy (Enudu, 2004).

For effective flow of information in the Igboland and beyond, the hierarchy should create a way of making both ordained and laity feel that they are in-group members (people that are trusted) and not out-group members (those who do not belong or cannot be trusted). This means that the church at the national level must be a home for everyone.

\section{Methodology}


This research work employed the use of primary and secondary sources to obtain data. The primary sources involve oral interviews while secondary sources involve the use of extant materials such as books, journals, artifacts, diaries, private and public brochures, homilies, archives, archaeological data and so on. The work is also based on historical and phenomenological approaches.

\section{Conclusion}

We have seen that despite the beauty inherent in unity in diversity as averred in John 17: 20-33, which serves as the epitome or as a tool for evangelisation denominationalism has attendant dangers. Devotion to the interests of a particular denomination is a narrowmindedness or parochial adherence to party spirit that often endangers effective evangelisation and creates spiritual and moral bankruptcy among the believers. The research work has averred that while engaging individual denominational evangelism, priests, religious and laity ought not to forget the importance of human relationship or interpersonal communication and witnessing. In using Information Communication Technology to relate the gospel intra-and inter-denominational witnessing, we must not be known for Facebook without facing-God or without sacrifice, owing a gmail account without a guarded moral, operating Yahoo without Yahweh and accessing Google without the gospel.

The different religions are to be used as building stones for the development of human culture in which the adherents of the different religions may be fraternally united as children of one Supreme. All religions convey to their followers a message of abiding hope. The world will give birth to a new faith that will be but the old faith in another form, the faith of all ages, the potential divinity of man which will work for the supreme purpose written in our hearts and souls, the unity of all mankind. It is my hope and 
prayer that unbelief shall disappear and superstition shall not enslave the mind and Christians shall recognise that they are brothers, one in spirit and one in fellowship.

Christians tolerance must be based not on indifference but on love. Christians, ought to be tolerant not because we could care less, but because we look at the other person with eyes of love. When Abraham Lincoln was criticized for being too courteous to his enemies and reminded that it was his duty to destroy them, he gave the great answer, "Do I not destroy my enemies when I make them my friends?" Even if a man be utterly mistaken, we must never regard him as an enemy to be destroyed but as a strayed friend to be recovered by love.

\section{Patrick Enoch Nmah}

Department of Religion \& Human Relations NnamdiAzikiwe University, Awka Nigeria

E-mail: patricknmah@yahoo.com

\section{References}

Anyika, F. and Ekebuisi, C. (2010). A hundred years of Methodism in Eastern Nigeria, 1910-2010: Genesis \& growth. Aba: Soul Winners Publications.

Ayandele, E.A. (1966). The missionary impact on modern Nigeria 18421914. London: Longmans, Green and Co. Ltd.

Barclay, W. (1982). The daily study Bible: The gospel of Luke. Edinburgh: The Saint Andrew Press.

Chiegboka, A.B.C. (2009). Punishment to parents in marriages between Catholics and non-Catholics: A reflection on canon 1366 in our local Church context. Nimo: Rex Charles \& Patrick.

Douglas, J.D. (Ed.). (1974). The new international dictionary of the Christian Church. Grand Rapids: Zondervan Publishing. 
Ekpunobi, E. (2001). We are closer than we think: An analysis of contemporary issues in ecumenism. Enugu: Rabboni.

Enudu, T.O. (2004). Introduction to business management. Enugu: Johnkens and Willy Publication.

Kalu, O. (1978). Christianity in West Africa: The northern story. Ibadan: Daystar.

Livingstone, E.A. (Ed.). (1980). The concise Oxford dictionary of the Christian Church. Oxford: Oxford University Press.

Methodist Church Nigeria (2010). One hundred years of Methodism in Isuikwuato, 1910-2010. Enugu: SAN Press.

Nmah, P.E. (2008). Missionary rivalry and evangelism in Igboland, 1850-1970: A reappraisal. Flash Journal of Philosophy and Religion, Volume 2, No. 1, 17-22.

Oldman, J.H. (1924). Christianity and the race problem. London: Student Christian Movement.

Uka, E.M. (1980). Moratorium, ideology or utopia? A sociological interpretation of African response to Christian mission. Unpublished Ph.D. Dissertation. New Jersey: Drew University Madison.

Willis, J. (2007). A handy GK book, A to Z of world religions: places, prophets, saints and seers. Mumbai: Jaico Publishing House. 